\title{
A TAXONOMIC STUDY OF THE BASIDIOMYCETOUS YEAST GENERA RHODOSPORIDIUM BANNO AND RHODOTORULA HARRISON BASED ON WHOLE- CELL PROTEIN PATTERNS, DNA BASE COM- POSITIONS AND COENZYME Q TYPES
}

\author{
MARC VANCANNEYT, ${ }^{*}$ RENATA COOPMAN, RICHARD TYTGAT, \\ JEAN-FRANÇOIS BERNY, ${ }^{1}$ GREGOIRE L. HENNEBERT, ${ }^{1}$ \\ AND KAREL KERSTERS \\ Laboratorium voor Microbiologie, Universiteit Gent, 9000 Gent, Belgium \\ ${ }^{I}$ Mycothèque de l'Université Catholique de Louvain, \\ 1348 Louvain-la-Neuve, Belgium \\ (Received June 29, 1992)
}

\begin{abstract}
A numerical analysis was performed on one-dimensional whole-cell protein electrophoretic fingerprints of 107 strains belonging to the basidiomycetous yeast genera Rhodosporidium and Rhodotorula. This technique allowed evaluation of taxonomic relationships at the species level. In particular for the anamorphic genus Rhodotorula, the electrophoretic groupings did not correspond in all cases with the existing species. Heterogeneity of strains within the anamorphic species Rhodotorula $a$ cheniorum, $R t$. aurantiaca, $R$ t. araucariae, $R$ t. foliorum, $R t$. glutinis, $R t$. graminis and $R t$. minuta was found. There was a good correlation between the grouping obtained by numerical analysis of protein patterns, the mol\% G $+\mathrm{C}$ content and the coenzyme $\mathrm{Q}$ type. Furthermore, the results obtained with the different techniques used suggest possible close interspecific and/or intergeneric relationships. Most Rhodotorula glutinis strains, including the type strain, and the type strain of Rhodotorula graminis were highly similar to strains of Rhodosporidium diobovatum. For other investigated strains of Rhodotorula glutinis, a high similarity was found with strains of Rhodosporidium kratochvilovae, Rs. sphaerocarpum, Rs. toruloides and Rhodotorula mucilaginosa, respectively. Most of the Rhodotorula graminis strains could not be differentiated from Rhodosporidium paludigenum strains.
\end{abstract}

* Address reprint requests to: Dr. Marc Vancanneyt, Laboratorium voor Microbiologie, K.L. Ledeganckstraat, 35, B-9000 Gent, Belgium. 
A natural system of yeast classification should be based on the coordinate use of morphological, physiological, biochemical and molecular information(17). Molecular approaches based on the DNA base composition (2,9-12,14), DNADNA homology (3), electrophoretic patterns of enzymes (24), rDNA sequencing results $(19,22,23)$, the ubiquinone system $(14,21)$ and the cellular carbohydrate composition (14) documented the heterogeneity of the genera Rhodosporidium and Rhodotorula. Based on these newly developed criteria, species of the genus Rhodosporidium have been reclassified in the genera Cystofilobasidium and Kondoa $(5,13,22)$. Weijman et al. (18) emended the anamorphic yeast genus Rhodotorula because of the reassignment of the Candida species of basidiomycetous affinity to the genera Cryptococcus and Rhodotorula. In particular, the taxonomy of the anamorphic yeasts remains controversial by a lack of the characteristics of the sexual reproduction and many genera will have to be reclassified in the future.

Although there has been much progress in the taxonomy and diagnosis of yeast species, there is a continuing need for simple and reliable laboratory procedures to differentiate these organisms. With an increasing number of species, it became obvious that the conventional diagnostic tests frequently provided insufficient phenotypic characterization to permit unambiguous assignment at the species level.

In previous papers, sodium dodecyl sulphate-polyacrylamide gel electrophoresis of whole-cell proteins (SDS-PAGE) proved to be a valuable criterion for classifying yeasts at the species level because of its high levels of sensitivity and selectivity $(15,16)$. Moreover, the ready availability and reproducibility of SDSPAGE and the possibility of computerized processing of data suggest a method useful for analytical characterization of yeasts.

In this paper, the results of comparative protein electrophoresis in the genera Rhodosporidium and Rhodotorula species are presented. To evaluate the taxonomic validity of this technique additional chemotaxonomical criteria such as the DNA base composition and the type of the ubiquinone system are used. Relying on these results and the literature data, the possible relationships among different strains and species in the genera Rhodosporidium and Rhodotorula are discussed.

\section{MATERIALS AND METHODS}

Strains examined. A total of 107 strains were studied. These included 23 strains representing 6 species in the genus Rhodosporidium, 82 strains belonging to 23 different Rhodotorula species and two Rhodotorula strains for which the species assignments were not known. The strains used are listed in Table 1.

Electrophoretic pattern of whole-cell proteins. All the strains were analyzed by electrophoresis of whole-cell proteins. The methods used for cultivation of cells and the preparation and electrophoresis of the SDS-protein extracts have been described elsewhere (16). The densitometric analysis, normalization and interpolation of the protein profiles, numerical analysis, and construction of a database were performed using the GelCompar 1.3 software package (Helix C. V., Biotechnology Business 
Table 1. List of strains studied, the source of isolation, the major coenzyme Q type and the DNA base composition (superscripts $\mathrm{c}$ to $\mathrm{m}$ indicate literature data; T, NT and

AUT indicate type strains, neo-type strains and authentic strains, respectively).

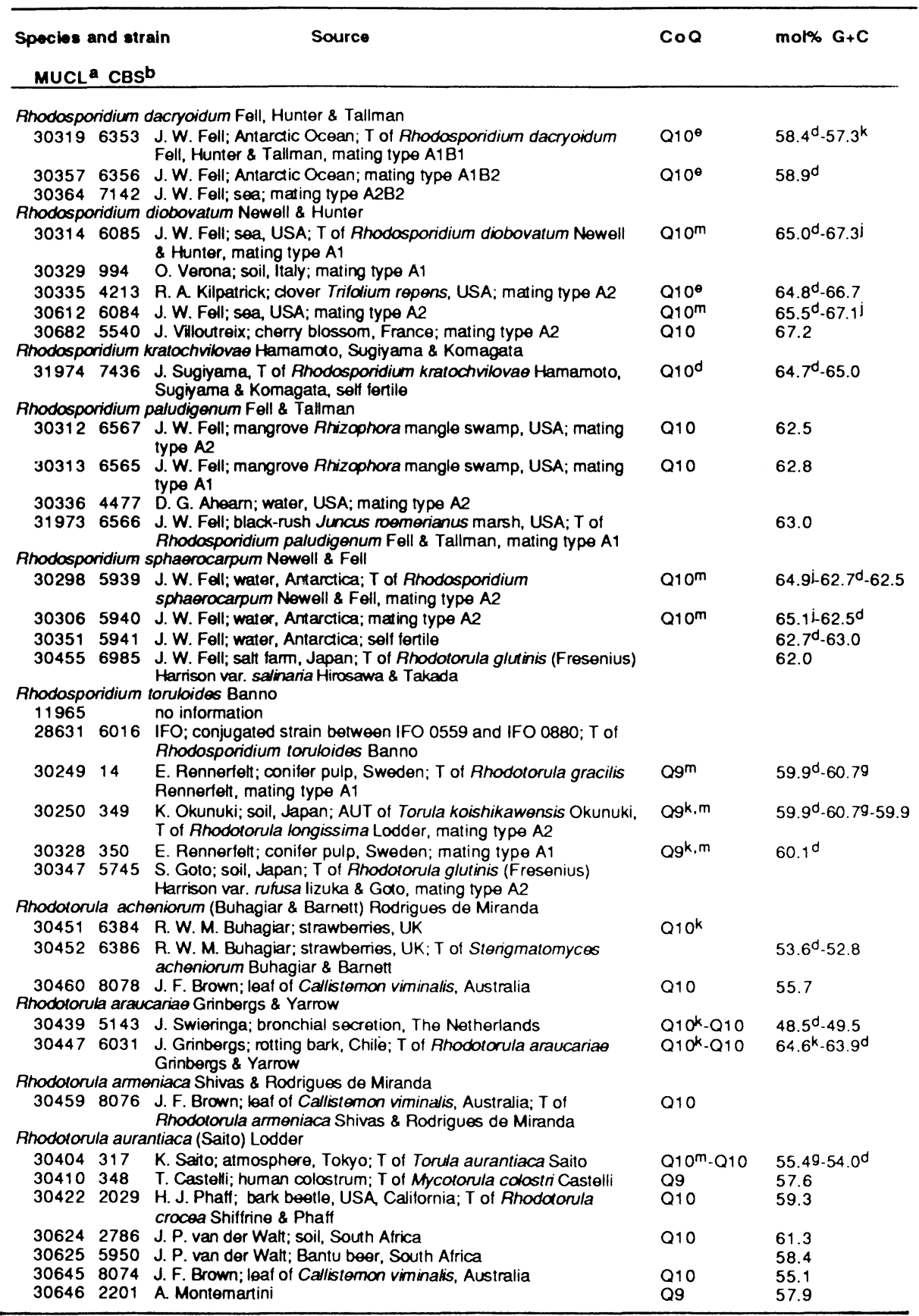


Table 1. (continued)




Table 1. (continued)

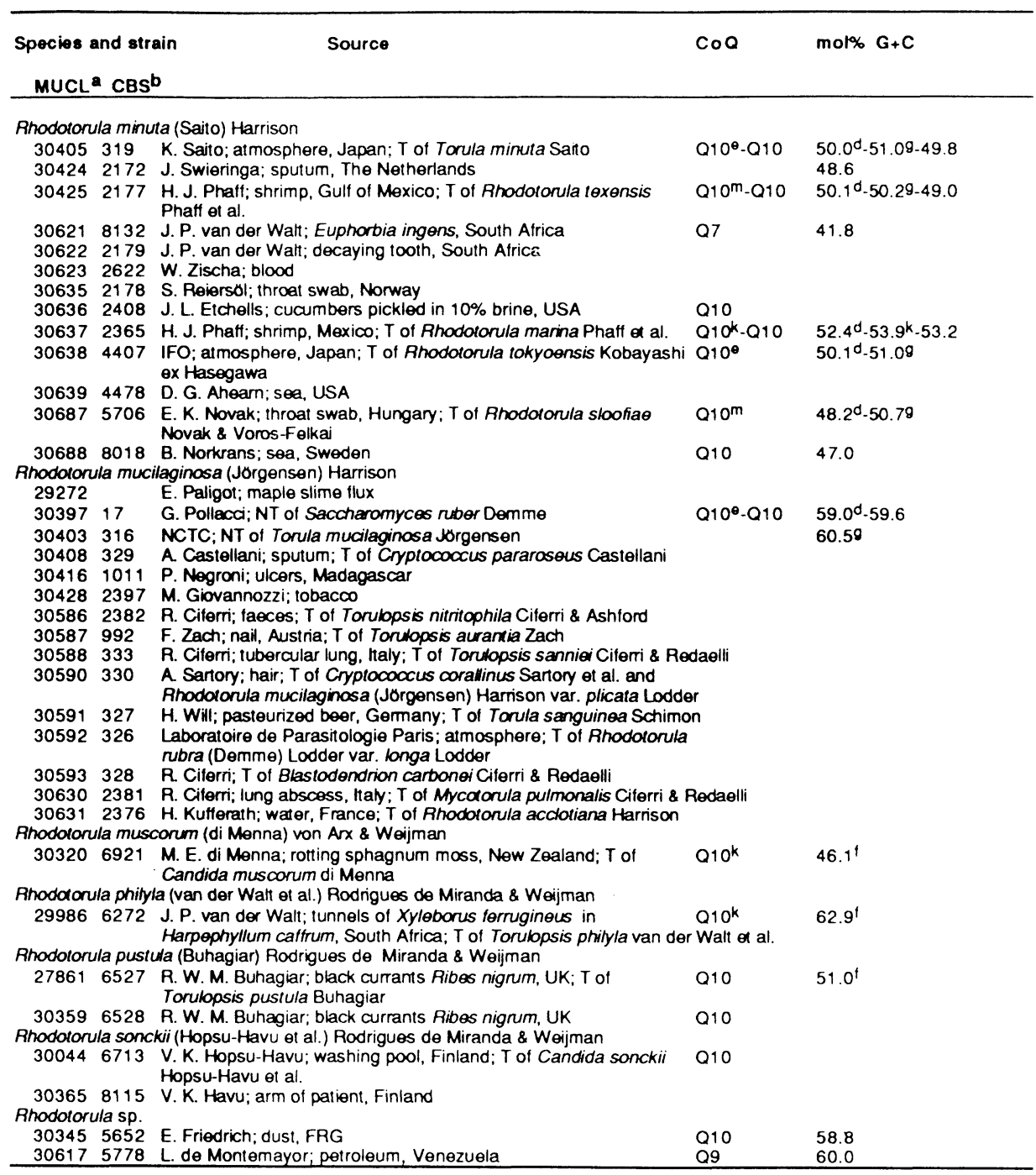

a MUCL, Mycothéque de l'Université de Louvain, Laboratoire de Mycologie Systématique et Appliquée, UCL Louvain-laNeuve, Belgium: b CBS, Centraalbureau voor Schimmelcultures, Baarn, The Netherlands; c Barnett et al. (1); ${ }^{\circ}$ Hamamoto et al. (2); ${ }^{\theta}$ Hamamoto et al. (3); ${ }^{\dagger}$ Kreger-van Rij (6); 9 Nakase and Komagata (9); ${ }^{h}$ Nakase and Komagata (19); ${ }^{i}$ Nakase and Komagata (11): i Nakase and Komagata (12); ${ }^{k}$ Sugiyama et al. (14); ' Yamada and Kondo (20): $\mathrm{m}$ Yamada and Kondo (21)

Development, Gent, Belgium). The profiles were recorded and stored on a PC-AT computer. The similarity between all pairs of traces (using points 10 to 285 of the 400 points of each interpolated trace) was expressed by the Pearson product moment correlation coefficient $r$.

Isolation and purification of DNA and determination of DNA base composition. 
Yeast strains were inoculated in $100 \mathrm{ml}$ GYPP (per liter distilled water: $20 \mathrm{~g}$ glucose, $5 \mathrm{~g}$ yeast extract, $10 \mathrm{~g}$ peptone, $0.025 \mathrm{M}$ phosphate buffer, $\mathrm{pH} 7.5$ ) in $500 \mathrm{ml}$ Erlenmeyer flasks and incubated at room temperature for $24 \mathrm{~h}$. Each liquid culture was transferred to $900 \mathrm{ml} \mathrm{GYPP}$ broth in a $5 l$ Erlenmeyer flask and incubated for a further period of $24-48 \mathrm{~h}$ while shaking. Cells were washed twice in $0.02 \mathrm{M}$ EDTA (pH 8.0). High molecular weight DNA was isolated by grinding the lyophilized yeast cells $(1-3 \mathrm{~g})$ in a mortar in the presence of liquid nitrogen. The ground cells were then suspended in extraction buffer $(0.2 \mathrm{M}$ Tris- $\mathrm{HCl}, 0.25 \mathrm{M}$ $\mathrm{NaCl}, 0.025 \mathrm{M}$ EDTA, pH 8.5). Proteinase K $(50 \mu \mathrm{g} / \mathrm{ml})$ and SDS $(20 \mathrm{~g} / l)$ were added and the lysed cell suspension was incubated for $3 \mathrm{~h}$ at $37^{\circ} \mathrm{C}$. The subsequent procedure for isolation and purification of DNA followed the method described by Marmur (7) with minor modifications. The DNA base composition was calculated from the thermal denaturation temperature of the DNA $\left(T_{\mathrm{m}}\right)$ using the formula of Marmur and Doty (8). The $T_{\mathrm{m}}$ value was determined in $0.5 \times \mathrm{SSC}$ solution using a Gilford spectrophotometer.

Extraction, purification and identification of ubiquinones. The organisms were grown as shaking cultures, as described above for the determination of the DNA base composition. Cells were harvested by centrifugation after $48 \mathrm{~h}$ and washed three times with distilled water. The washed cells $(3-6 \mathrm{~g})$ were transferred to a 500 $\mathrm{ml}$ flask. For saponification $50 \mathrm{ml}$ distilled water, $100 \mathrm{ml}$ methanol, $20 \mathrm{~g}$ sodium hydroxide and $5 \mathrm{~g}$ pyrogallol were added and the mixture was heated at $90^{\circ} \mathrm{C}$ during $1 \mathrm{~h}$ in a water bath. Ubiquinones were extracted with hexane from intact cells after saponification according to the method described by Yamada and Kondo (21), and isolated by preparative thin-layer chromatography using Kieselgel $60 \mathrm{~F}_{254}$ (Merck, Darmstadt, Germany) plates and benzene as a solvent system. Ubiquinone isoprenologues were identified by high performance liquid chromatography (HPLC) by comparing then retention times with those of standard ubiquinones from $\mathrm{Q}_{6}$ to $\mathrm{Q}_{10}$ (Sigma Chemical Co., St. Louis, MO, USA). HPLC was performed on a liquid chromatograph (Waters, Milford, MA, USA) equipped with a Zorbax ODS column $(4.6 \mathrm{~mm} \times 25 \mathrm{~cm}$; Chrompack International B. V., Middelburg, The Netherlands). Ubiquinone isoprenologues were eluted with a mobile phase of methanol-isopropanol $(3: 1, \mathrm{v} / \mathrm{v})$ at $1 \mathrm{ml} / \mathrm{min}$, and monitored at $275 \mathrm{~nm}$.

\section{RESULTS AND DISCUSSION}

A dendrogram obtained after numerical analysis of protein electrophoregrams of 107 Rhodosporidium and Rhodotorula strains is shown in Fig. 1. The overall reproducibility of the electrophoresis technique averaged $r=0.94$. Also a good reproducibility ( $r \geq 0.94)$ was found between the protein patterns from duplicated

Fig. 1. Dendrogram based on average linkage cluster analysis of SDS-PAGE protein patterns of 107 strains of the basidiomycetous genera Rhodosporidium and Rhodotorula (Rs., Rhodosporidium; Rt., Rhodotorula). 


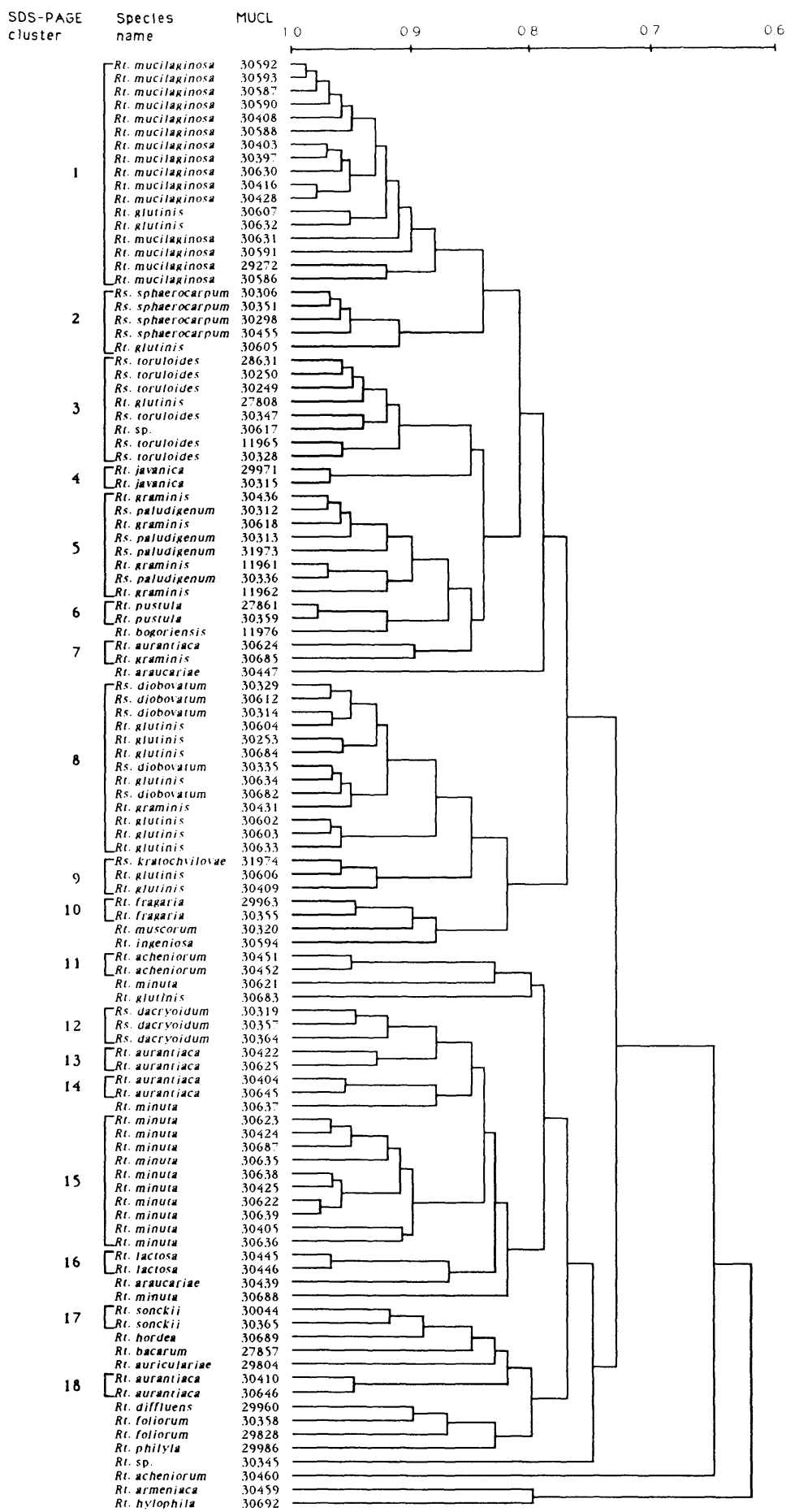

Fig. 1 
cultures (data not shown). Eighteen clusters are delineated at a correlation level of approximately $r=0.90$. These clusters group visually highly similar protein profiles (Fig. 2). Within each cluster only minor quantitative differences are observed. Data concerning the DNA base composition and the ubiquinone type (Table 1) are used to evaluate the grouping obtained by numerical analysis of the protein profiles. In the present study, determination of the $\mathrm{mol} \% \mathrm{G}+\mathrm{C}$ content is repeated for several strains for which the value was reported earlier. It allows to evaluate in some cases the somewhat aberrant data reported by different authors. The relative standard error of the thermal denaturation method in this work is less than $1.0 \%$ (data not shown).

\section{The genus Rhodosporidium}

The delineation and intraspecific homogeneity of species of the basidiomycetous genus Rhodosporidium based on morphological and phenotypical characteristics $(1,6)$ are confirmed by numerical analysis of whole-cell protein patterns $(16$, Fig. 1), determination of the DNA base compositions and the coenzyme Q systems (Table 1). Except for Rhodosporidium toruloides, all Rhodosporidium species possess the coenzyme $\mathrm{Q}_{10}$ system $(3,21$, Table 1).

Three Rhodosporidium dacryoidum strains constitute the protein electrophoretic cluster $12(r \geq 0.92$; Fig. 1) and are characterized by a mol $\% \mathrm{G}+\mathrm{C}$ of $57.3-58.9 \%(2,14)$.

Five Rhodosporidium diobovatum strains belong to SDS-PAGE cluster 8 ( $r \geq$ 0.88 ; Fig. 1). Data of different authors demonstrate a considerable variation in the $\mathrm{mol} \% \mathrm{G}+\mathrm{C}$ content. A different range from 67.1 to $67.3 \%$ and from 64.8 to $65.5 \%$ is reported by Nakase and Komagata (12) and Hamamoto et al. (2), respectively. Results from the present study show a DNA base composition of 66.7 and $67.2 \mathrm{~mol} \% \mathrm{G}+\mathrm{C}$ for Rhodosporidium diobovatum MUCL 30335 and MUCL 30682, respectively. Similar DNA base compositions are detected for representative strains of other species within cluster 8 (see below).

The type strain of Rhodosporidium kratochvilovae groups in SDS-PAGE cluster $9(r \geq 0.93$; Fig. 1$)$ and is characterized by a DNA base composition of $65.0 \mathrm{~mol}$ $\% \mathrm{G}+\mathrm{C}$, which confirms the value of $64.7 \%$ obtained by Hamamoto et al. $(2,4)$.

Four Rhodosporidium paludigenum strains group in SDS-PAGE cluster 5 ( $r \geq$ 0.90 ; Fig. 1). Representative strains have a DNA base composition of 62.5-63.0 $\mathrm{mol} \% \mathrm{G}+\mathrm{C}$ (Table 1).

Four Rhodosporidium sphaerocarpum strains group in SDS-PAGE cluster 2 $(r \geq 0.91$; Fig. 1) and a DNA base composition is found in the range of 62.0-63.0

Fig. 2. SDS-protein electrophoregrams of 58 representative strains from the clusters obtained by numerical analysis (Rs., Rhodosporidium; Rt., Rhodotorula). The positions of the molecular weight markers (track labeled MWM) are indicated from left to right: lysozyme, 14,500; trypsin inhibitor, 20,100; carbonic anhydrase, 29,000; glyceraldehyde-3-phosphate dehydrogenase, 36,000; egg albumin, 45,000; bovine albumin, 66,000; $\beta$-galactosidase, 116,000. 


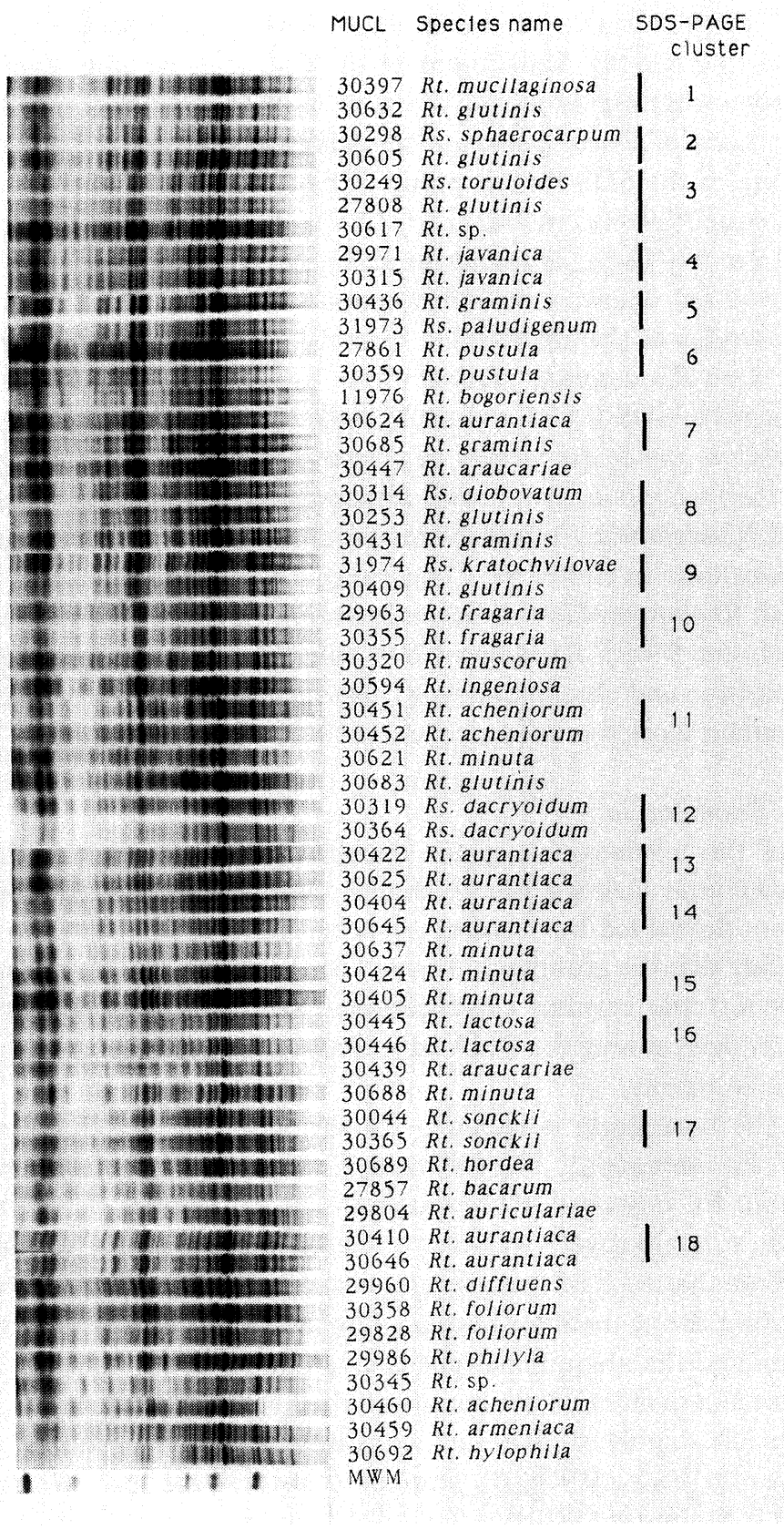

Fig. 2 
$\mathrm{mol} \% \mathrm{G}+\mathrm{C}$ (Table 1). A similar DNA base composition of $62.5-62.7 \mathrm{~mol} \%$ $\mathrm{G}+\mathrm{C}$ was detected by Hamamoto et al. (2). Nakase and Komagata (12) reported a somewhat higher mol\% $\mathrm{G}+\mathrm{C}$ of $64.9-65.1 \%$.

The strains of Rhodosporidium toruloides, possessing the ubiquinone $\mathrm{Q}_{9}$ type (21), belong to the SDS-PAGE group $3(r \geq 0.91$; Fig. 1$)$ and show a DNA base composition of $59.9-60.7 \mathrm{~mol} \% \mathrm{G}+\mathrm{C}(2,9)$. In this study a DNA base composition of $59.9 \mathrm{~mol} \% \mathrm{G}+\mathrm{C}$ is found for strain MUCL 30250 .

As discussed below, some Rhodosporidium species show similar protein patterns with strains of the anamorphic species Rhodotorula glutinis and Rt. graminis (Fig. 1). One Rhodotorula glutinis strain groups with Rhodosporidium sphaerocarpum strains in SDS-PAGE cluster 2, one Rhodotorula glutinis strain groups with Rhodosporidium toruloides strains in cluster 3, seven Rhodotorula glutinis strains, including the type strain, group with Rhodosporidium diobovatum strains in cluster 8 , and two Rhodotorula glutinis strains group with the type strain of Rhodosporidium kratochvilovae in cluster 9. Concerning Rhodotorula graminis, the type strain groups with Rhodosporidium diobovatum strains in cluster 8 and four other strains group in cluster 5 with Rhodosporidium paludigenum strains. Other data (DNA base composition and ubiquinone type) also suggest that the protein electrophoretic clusters contain closely related strains (see below).

\section{The genus Rhodotorula}

Unlike the teleomorphic genus Rhodosporidium, species of the anamorphic genus Rhodotorula lack the morphological characteristics of the sexual reproduction and are delineated by classical phenotypical tests $(1,6)$. The results of this study indicate that the groupings obtained by the whole-cell protein patterns do not always support the existing classification. We have evaluated the SDS-PAGE technique by determining the DNA base composition and the ubiquinone type from representative strains.

Only the type strain is included for the following ten species: Rhodotorula armeniaca, Rt. auriculariae, Rt. bacarum, Rt. bogoriensis, Rt. diffluens, Rt. hordea, $R t$. hylophila, Rt. ingeniosa, Rt. muscorum and Rt. philyla. All these type strains demonstrate a qualitatively well-characterized protein profile (Figs. 1, 2), which might indicate that each of these species occupies a unique and separate taxonomic position within the genus Rhodotorula. For several of these strains, the DNA base composition and the ubiquinone type is given in Table 1.

The protein profiles of the strains studied belonging to each of the following five species are highly similar and constitute a separate cluster: Rhodotorula fragaria (cluster 10; $r \geq 0.95$ ), Rt. javanica (cluster $4 ; r \geq 0.97$ ), Rt. lactosa (cluster 16; $r \geq 0.97$ ), Rt. pustula (cluster 6; $r \geq 0.98$ ) and $R$ t. sonckii (cluster $17 ; r \geq 0.92$ ). Data concerning the DNA base composition and the ubiquinone type of strains of these clusters are indicated in Table 1 .

Intraspecific heterogeneity is demonstrated within the following seven species: Rhodotorula acheniorum, Rt. araucariae, Rt. aurantiaca, Rt. foliorum, Rt. glutinis, 
Rt. graminis and Rt. minuta. For each of these species, the observed protein electrophoretic heterogeneity is evaluated below, relying on the DNA base composition and the ubiquinone type.

Two strains of Rhodotorula acheniorum, the type strain MUCL 30452 and strain MUCL 30451, exhibit highly similar protein patterns $(r=0.95)$ and group in cluster 11. A third strain MUCL 30460 displays a distinct protein profile (a correlation level $r=0.65$ with cluster 11 ). The difference between the latter strain and the strains from cluster 11 is confirmed by a difference in $\mathrm{mol} \% \mathrm{G}+\mathrm{C}$. For the type strain MUCL 30452 a DNA base composition of $52.8 \mathrm{~mol} \% \mathrm{G}+\mathrm{C}$ is determined, which is analogous with the value of $53.6 \%$ mentioned by Hamamoto et al. (2). A significant different DNA base composition of $55.7 \mathrm{~mol} \% \mathrm{G}+\mathrm{C}$ is observed for strain MUCL 30460. The presence of the coenzyme $\mathrm{Q}_{10}$ system is reported for a representative strain of cluster 11 (14) and for strain MUCL 30460 (Table 1).

Two Rhodotorula araucariae strains produce highly distinct protein profiles $(r=0.73)$. Although both strains possess the coenzyme $\mathrm{Q}_{10}$ system (14), the observed heterogeneity in protein pattern is confirmed by a difference in DNA base composition. Strain MUCL 30439 is characterized by a mol\% G+C of $49.5 \%$, which confirms the value of $48.5 \%$ obtained by Hamamoto et al. (2), while the type strain MUCL 30447 has a much higher DNA base composition of 63.9-64.6 mol\% $\mathrm{G}+\mathrm{C}(2,14)$.

Seven Rhodotorula aurantiaca strains yield four qualitatively different protein profiles. Cluster 13 groups the strains MUCL 30422 and MUCL $30625(r=0.93)$, two strains characterized by the coenzyme $Q_{10}$ system and a DNA base composition of $58.4-59.3 \mathrm{~mol} \% \mathrm{G}+\mathrm{C}$ (Table 1). Cluster 14 groups the type strain of Rhodotorula aurantiaca MUCL 30404 and strain MUCL $30645(r=0.96)$. Besides a highly similar protein pattern, both strains are characterized by the coenzyme $\mathrm{Q}_{10}$ system and an analogous DNA base composition of $54.0-55.4 \mathrm{~mol} \% \mathrm{G}+\mathrm{C}(2,9$, Table 1). In protein cluster 18, Rhodotorula aurantiaca strains MUCL 30410 and MUCL 30646 group at a correlation level $r=0.95$. In contrast with other strains studied of this species, both strains show the coenzyme $\mathrm{Q}_{9}$ system (Table 1). These strains share a homologous DNA base composition of $57.6-57.9 \mathrm{~mol} \% \mathrm{G}+\mathrm{C}$ (Table 1). Strain MUCL 30624 shows a similar protein profile with $R t$. graminis MUCL 30685 and groups in cluster 7 ( $r=0.90$; Fig. 1). Both strains are characterized by a similar DNA base composition of $61.3 \mathrm{~mol} \% \mathrm{G}+\mathrm{C}$ and the coenzyme $\mathrm{Q}_{10}$ system (Table 1).

Two Rhodotorula foliorum strains studied, the type strain MUCL 29828 and MUCL 30358, show a protein electrophoretic similarity of $r=0.87$. This low correlation level is confirmed by a different DNA base composition of 55.5 and 52.0 $\mathrm{mol} \% \mathrm{G}+\mathrm{C}$, respectively. Both strains possess the coenzyme $\mathrm{Q}_{10}$ system.

The Rhodotorula glutinis strains studied are in terms of protein electrophoretic similarity heterogeneous and are scattered over six taxonomic groups (Fig. 1). This grouping is confirmed by the results of the determination of the DNA base 
composition and the ubiquinone type (Table 1). Two strains of the species, MUCL 30607 and MUCL 30632, show a similar electrophoretic protein pattern with the Rhodotorula mucilaginosa strains and belong to cluster 1 ( $r \geq 0.88)$ (Figs. 1 and 2). All strains of this group are characterized by the coenzyme $\mathrm{Q}_{10}$ system (Table 1). A similar DNA base composition varying between 59.0 and $60.5 \mathrm{~mol} \% \mathrm{G}+\mathrm{C}$ for Rhodotorula mucilaginosa strains (2,9, Table 1) and 60.3 and $60.7 \%$ for the strains MUCL 30607 and MUCL 30632, respectively, confirms that all these strains could be closely related. The inadequacy of discrimination between Rhodotorula glutinis and Rhodotorula mucilaginosa strains based on the ability to assimilate nitrate is already suggested by Hamamoto et al. (3) and is confirmed here by SDS-PAGE.

One strain of Rhodotorula glutinis MUCL 30605 groups in SDS-PAGE cluster 2 with all strains investigated of Rhodosporidium sphaerocarpum $(r \geq 0.91)$. These strains are characterized by the coenzyme $\mathrm{Q}_{10}$ system (21, Table 1). The DNA base composition of Rhodotorula glutinis MUCL 30605 is $62.8 \mathrm{~mol} \% \mathrm{G}+\mathrm{C}$ and is analogous to the values of $62.0-63.0 \%$ for Rhodosporidium sphaerocarpum strains. The latter data are in accordance with those of Hamamoto et al. (2). The data presented in this study suggest that strain MUCL 30605 might be an anamorphic strain of Rhodosporidium sphaerocarpum.

Another strain of Rhodotorula glutinis MUCL 27808 and the unidentified Rhodotorula strain MUCL 30617 show highly similar protein profiles with Rhodosporidium toruloides strains and group in cluster $3(r \geq 0.91)$. Both strains are characterized by the coenzyme $\mathrm{Q}_{9}$ system and a DNA base composition of 60.0 $\mathrm{mol} \% \mathrm{G}+\mathrm{C}$. Similar characteristics for strains of Rhodosporidium toruloides are reported (2,21). This suggests that Rhodotorula glutinis MUCL 27808 and the unidentified Rhodotorula strain MUCL 30617 might be anamorphic strains of Rhodosporidium toruloides.

The majority of the Rhodotorula glutinis strains, the type strains MUCL 30253 and six other strains studied (MUCL 30602, MUCL 30603, MUCL 30604, MUCL 30633, MUCL 30634 and MUCL 30684) show similar protein profiles with the Rhodosporidium diobovatum strains studied and belong to cluster $8(r \geq 0.88)$. All these strains possess the ubiquinone $Q_{10}$ type (21, Table 1). They also share a similar DNA base composition varying between 66.4 and $67.1 \mathrm{~mol} \% \mathrm{G}+\mathrm{C}$ for the Rhodotorula glutinis strains and ranging from 66.7 to $67.3 \%$ for the Rhodosporidium diobovatum strains (12, Table 1). A possible anamorph-teleomorph relationship between some strains of Rhodotorula glutinis and Rhodosporidium diobovatum is suggested by Hamamoto and coworkers (3). Our results confirm this statement for the strains grouping in cluster 8 .

Two strains of Rhodotorula glutinis MUCL 30409 and MUCL 30606 group with the type strain of Rhodosporidium kratochvilovae MUCL 31974 in the SDSPAGE cluster $9(r \geq 0.93)$. The latter strain is characterized by the coenzyme $Q_{10}$ system (21) and a DNA base composition of $64.7-65.0 \mathrm{~mol} \% \mathrm{G}+\mathrm{C}(2$, Table 1). Rhodotorula glutinis MUCL 30409 and MUCL 30606 also possess the ubiquinone $\mathrm{Q}_{10}$ type and have a DNA base composition of 64.9 and $64.2 \mathrm{~mol} \% \mathrm{G}+\mathrm{C}$, 
respectively (Table 1). These data suggest that MUCL 30409 and MUCL 30606 might be considered as anamorphic strains of the self-sporulating species Rhodosporidium kratochvilovae. Hamamoto et al. (4) already classified two Rhodotorula glutinis strains in the species Rhodosporidium kratochvilovae based on similar chemotaxonomic data.

In comparison with other Rhodotorula glutinis strains studied, strain MUCL 30683 demonstrates a unique protein pattern (Fig. 1) and a significantly higher DNA base composition of $68.9 \mathrm{~mol} \% \mathrm{G}+\mathrm{C}$. The strain is characterized by the coenzyme $\mathrm{Q}_{10}$ system (Table 1).

Six Rhodotorula graminis strains are investigated. The type strain of this species groups in cluster 8 together with strains of Rhodotorula glutinis, including the type strain, and all strains investigated of Rhodosporidium diobovatum. The observed DNA base composition of $66.9 \mathrm{~mol} \% \mathrm{G}+\mathrm{C}$ is analogous with the reported value of $67.0 \%(2)$, and is furthermore similar to the values of other strains of cluster 8 (see above). In addition, all strains studied of this protein electrophoretic group possess the coenzyme $Q_{10}$ system (Table 1). These data indicate that the type strain of $R$ hodotorula graminis might be an anamorphic strain of Rhodosporidium diobovatum, as is suggested in the present study and by Hamamoto et al. (3) for the majority of the strains of Rhodotorula glutinis.

Four Rhodotorula graminis strains (MUCL 11961, MUCL 11962, MUCL 30436 and MUCL 30618) group in the protein electrophoretic cluster 5 with all Rhodosporidium paludigenum strains investigated $(r \geq 0.90)$. A possible close relatedness between strains of this cluster is confirmed by an analogous DNA base composition of $63.0 \mathrm{~mol} \% \mathrm{G}+\mathrm{C}$ for representative Rhodotorula graminis strains and a range of 62.5 to $63.0 \%$ for Rhodotorula paludigenum strains. Moreover, the coenzyme $\mathrm{Q}_{10}$ system is found in representative strains of cluster 5 .

Rhodotorula graminis MUCL 30685 groups in the protein electrophoretic cluster 7 with $R t$. aurantiaca MUCL $30624(r=0.90)$. Both strains are characterized by a similar DNA base composition of $61.3 \mathrm{~mol} \% \mathrm{G}+\mathrm{C}$ (Fig. 1). An analogous value of $62.0 \%$ is reported for strain MUCL 30685 (2). Both strains possess the coenzyme $Q_{10}$ system (21). Relying on the partial sequences of the $18 \mathrm{~S}$ and 26S rRNA, Yamada et al. (23) have demonstrated that this strain is related to Rhodosporidium sphaerocarpum and $R$ s. paludigenum.

Thirteen strains of the species Rhodotorula minuta are investigated. Ten strains group in protein cluster 15 and are characterized by a DNA base composition varying between 48.2 and $51.0 \mathrm{~mol} \% \mathrm{G}+\mathrm{C}(2,19$, Table 1). These strains possess the coenzyme $\mathrm{Q}_{10}$ system $(3,21)$.

Two other coenzyme $\mathrm{Q}_{10}$-possessing Rhodotorula minuta strains, MUCL 30637 and MUCL 30688, show a different protein pattern with correlation levels of $r=$ 0.84 and $r=0.82$ versus cluster 15 strains, respectively. The heterogeneity of strains of this species is confirmed by determination of the DNA base composition which reveals a mol $\% \mathrm{G}+\mathrm{C}$ content of $53.2 \%$ for strain MUCL 30637 and $47.0 \%$ for strain MUCL 30688. 
Rhodotorula minuta MUCL 30621 displays a unique protein profile, a much lower DNA base composition of $41.8 \mathrm{~mol} \% \mathrm{G}+\mathrm{C}$ and an aberrant coenzyme Q system. The major ubiquinone component is $\mathrm{Q}_{7}$ and significant amounts (approximately $30 \%$ of the total amount) of the minor component coenzyme $\mathrm{Q}_{8}$ are observed (Table 1).

\section{Conclusions}

Previous work demonstrated that numerical analysis of one-dimensional protein electrophoretic patterns is extremely useful for the identification of yeast species. Furthermore, it allows a rapid and reliable grouping of a large number of strains $(15,16)$. Within several anamorphic Rhodotorula species (Rt. acheniorum, Rt. aurantiaca, Rt. araucariae, Rt. foliorum, Rt. glutinis, Rt. graminis and Rt. minuta), intraspecific differences in banding patterns are observed. The protein electrophoretic heterogeneity within these species is confirmed by differences in DNA base composition and/or the ubiquinone type of representative strains. These data suggest a very close relatedness between several of the Rt. glutinis strains studied, including the type strain, and the type strain of Rhodotorula graminis with strains of Rhodosporidium diobovatum. Other investigated strains of Rhodotorula glutinis show a close relationship with strains of Rhodosporidium kratochvilovae, $R$ s. sphaerocarpum, Rs. toruloides and Rhodotorula mucilaginosa, respectively. Most of the Rhodotorula graminis strains studied show a close relatedness to Rhodosporidium paludigenum strains. The application of additional taxonomic approaches relying on interfertility tests and DNA-DNA homology will be necessary to confirm these statements.

This paper presents results of the Belgian National Incentive Program on Fundamental Research in the Life Sciences initiated by the Belgian State, Prime Minister's Office, Science Policy Programming (grants $\mathrm{BIO} / 11$ and $\mathrm{BIO} / 14$ ). Part of this research was carried out in the framework of contract BIOT-CT91-0294 of the Commission of the European Communities.

\section{REFERENCES}

1) Barnett, J. A., Payne, R. W., and Yarrow, D., Yeasts: Characteristics and Identification. Second Edition, Cambridge University Press, Cambridge (1990).

2) Hamamoto, M., Sugiyama, J., and Komagata, K., DNA base composition of strains in the genera Rhodosporidium, Cystofilobasidium, and Rhodotorula determined by reversed-phase highperformance liquid chromatography. J. Gen. Appl. Microbiol., 32, 215-223 (1986).

3) Hamamoto, M., Sugiyama, J., and Komagata, K., DNA-DNA reassociation studies of strains in the genera Rhodosporidium and Rhodotorula. J. Gen. Appl. Microbiol., 33, $57-73$ (1987)

4) Hamamoto, M., Sugiyama, J., and Komagata, K., Rhodosporidium kratochvilovae sp. nov., a new basidiomycetous yeast species. J. Gen. Appl. Microbiol., 34, 119-125 (1988).

5) Hamamoto, M., Sugiyama, J., and Komagata, K., Transfer of Rhodosporidium infirmominiatum to the genus Cystofilobasidium as Cystofilobasidium infirmominiatum comb. nov. J. Gen. Appl. Microbiol., 34, 271-278 (1988).

6) Kreger-van Rij, N. J. W., The yeasts, a Taxonomic Study. Third Revised and Enlarged Edition, 
Elsevier Science Publishers B. V., Amsterdam (1984).

7) Marmur, J., A procedure for the isolation of deoxyribonucleic acid from microorganisms. J. Mol. Biol., 3, 208-218 (1961).

8) Marmur, J. and Doty, P., Determination of the base composition of DNA from its thermal denaturation temperature. J. Mol. Biol., 5. 109-118 (1962).

9) Nakase, T. and Komagata, K., Significance of DNA base composition in the classification of the yeast genera Cryptococcus and Rhodotorula. J. Gen. Appl. Microbiol., 17, 121-130 (1971).

10) Nakase, T. and Komagata, K., Significance of DNA base composition in the classification of the yeast genus Torulopsis. J. Gen. Appl. Microbiol., 17, 161-166 (1971).

11) Nakase, T. and Komagata, K., Significance of DNA base composition in the classification of the yeast genus Candida. J. Gen. Appl. Microbiol., 17, 259-279 (1971).

12) Nakase, T. and Komagata, K., DNA base composition of some species of yeasts and yeast-like fungi. J. Gen. Appl. Microbiol., 17, 363-369 (1971).

13) Oberwinkler, F., Bandoni, R., Blanz, P., and Kisimova-Horovitz, L., Cystofilobasidium: a new genus in the Filobasidiaceae. Syst. Appl. Microbiol., 4, 114-122 (1983).

14) Sugiyama, J., Fukagawa, M., Chiu, S., and Komagata, K., Cellular carbohydrate composition, DNA base composition, ubiquinone systems, and diazonium blue $\mathrm{B}$ color test in the genera Rhodosporidium, Leucosporidium, Rhodotorula and related basidiomycetous yeasts. J. Gen. Appl. Microbiol., 31, 519-550 (1985).

15) Vancanneyt, M., Pot, B., Hennebert, G., and Kersters, K., Differentiation of yeast species based on electrophoretic whole-cell protein patterns. Syst. Appl. Microbiol., 14, $23-32$ (1991).

16) Vancanneyt, M., Van Lerberge, E., Berny, J.-F., Hennebert, G. L., and Kersters, K., The application of whole-cell protein electrophoresis for the classification and identification of basidiomycetous yeast species. Antonie van Leeuwenhoek: J. Microbiol., 61, 69-78 (1992).

17) Viljoen, B. C. and Kock, J. L. F., A taxonomic study of the yeast genus Candida Berkhout. Syst. Appl. Microbiol., 12, 91-102 (1989).

18) Weijman, A. C. M., Rodrigues De Miranda, L., and van de Walt, J. P., Redefinition of Candida Berkhout and the consequent emendation of Cryptococcus Kützing and Rhodotorula Harrison. Antonie van Leeuwenhoek: J. Microbiol, 54, 545-553 (1988).

19) Yamada, Y. and Kawasaki, H., The molecular phylogeny of the $Q_{8}$-equipped basidiomycetous yeast genera Mrakia Yamada et Komagata and Cystofilobasidium Oberwinckler et Bandoni based on the partial sequences of $18 \mathrm{~S}$ and 26S rRNA. J. Gen. Appl. Microbiol., 35, 173-183 (1989).

20) Yamada, Y. and Kondo, K., Taxonomic significance of coenzyme Q system in yeasts and yeast-like fungi. In Proceedings of the First Specialized International Symposium on Yeasts, ed. by Kockova-Kratochvilova, A. and Minarek, E., Publishing House of the Slovak Academy of Sciences, Bratislava (1972), p. 363-372.

21) Yamada, Y. and Kondo, K., Coenzyme Q system in the classification of the yeast genera Rhodotorula and Cryptococcus, and the yeast-like genera Sporobolomyces and Rhodosporidium. J. Gen. Appl. Microbiol., 19, 59-77 (1973).

22) Yamada, Y., Nakagawa, Y., and Banno, I., The phylogenetic relationship of the Q $_{9}$-equipped species of the heterobasidiomycetous yeast genera Rhodosporidium and Leucosporidium based on the partial sequences of $18 \mathrm{~S}$ and $26 \mathrm{~S}$ rRNA: the proposal of a new genus Kondoa. J. Gen. Appl. Microbiol., 35, 377-385 (1989).

23) Yamada, Y., Nakagawa, Y., and Banno, I., The molecular phylogeny of the $Q_{10}$-equipped species of the heterobasidiomycetous yeast genus Rhodosporidium Banno based on the partial sequences of $18 \mathrm{~S}$ and 26 S ribosomal ribonucleic acids. J. Gen. Appl. Microbiol., 36, 435-444 (1990).

24) Yamazaki, M. and Komagata, K., Taxonomic significance of electrophoretic comparison of enzymes in the genera Rhodotorula and Rhodosporidium. Int. J. Syst. Bacteriol., 31, 361-381 (1981). 